\title{
PENGEMBANGAN MODUL KIMIA BERBASIS INKURI TERBIMBING PADA MATERI LARUTAN PENYANGGA UNTUK MENINGKATKAN KETERAMPILAN BERPIKIR KRITIS DAN KETERAMPILANPROSES SAINS SISWA KELAS XI IPA SMA
}

\author{
Indri Femiceyanti ${ }^{1}$, Sentot Budi Rahardjo ${ }^{2}$, Sri Yamtinah ${ }^{3}$ \\ ${ }^{1}$ Program Studi Magister Pendidikan Sains FKIP Universitas Sebelas Maret \\ Surakarta, 57126, Indonesia \\ femiceyantiindri@gmail.com \\ ${ }^{2}$ Program Studi Magister Pendidikan Sains FKIP Universitas Sebelas Maret \\ Surakarta, 57126, Indonesia \\ sentotbr@yahoo.com \\ ${ }^{3}$ Program Studi Magister Pendidikan Sains FKIP Universitas Sebelas Maret \\ Surakarta, 57126, Indonesia \\ jengtina_sp@yahoo.com
}

\begin{abstract}
Abstrak
Penelitian ini bertujuan untuk: (1) mengembangkan modul kimia berbasis inkuiri terbimbing untuk meningkatkan keterampilan berpikir kritis dan keterampilan proses sains pada materi larutan penyangga, (2) menguji kelayakan modul kimia berbasis inkuiri terbimbing untuk meningkatkan keterampilan berpikir kritis dan keterampilan proses sains pada materi larutan penyangga, (3) mengetahui efektivitas pembelajaran setelah menggunakan modul kimia berbasis inkuiri terbimbing pada materi larutan penyangga. Penelitian dilakukan di SMA Teladan Way Jepara, SMA N 1 Labuhan Maringgai, dan SMA Kosgoro Sribhawono di Kabupaten Lampung Timur. Penelitian pengembangan modul kimia ini menggunakan 9 tahapan prosedur Borg and Gall meliputi: (1) penelitian pendahuluan dan pengumpulan data, (2) perencanaan, (3) penge,bangan produk, (4) uji coba lapangan awal, (5) revisi produk awal, (6) uji coba pelaksanaan lapangan, (7) penyempurnaan produk hasil uji coba lapangan, (8) uji pelaksanaan lapangan, (9) penyempurnaan produk akhir. Analisis kelayakan modul berdasarkan skor kriteria. Analisis efektifitas modul menggunakan uji-t pihak kanan. Hasil penelitian menunjukkan bahwa: (1) modul kimia berbasis inkuiri terbimbing pada materi larutan penyangga telah dikembangkan dengan menggunakan 9 tahapan prosedur Borg and Gall. Modul tersebut dapat meningkatkan keterampilan berpikir kritis dan keterampilan proses sains. (2) modul kimia berbasis inkuiri terbimbing mendapat penilaian dengan kategori "Baik" sehingga layak digunakan pada proses pembelajaran (3) hasil uji efektivitas menunjukkan bahwa modul kimia berbasis inkuiri terbimbing efektif digunakan pada sekolah dengan kategori tinggi,sedang dan rendah. Hal ini ditunjukkan dengan rata-rata prestasi belajar kelas eksperimen lebih tinggi dibandingkan kelas kontrol.
\end{abstract}

Kata Kunci: modul kimia, inkuiri terbimbing, keterampilan berpikir kritis, keterampilan proses sains, larutan penyangga

\section{Pendahuluan}

Dalam era globalisasi dewasa ini, tantangan peningkatan mutu dalam berbagai aspek kehidupan tidak dapat ditawar lagi. Pesatnya perkembangan IPTEKS dan tekanan globalisasi yang menghapuskan tapal batas antarnegara, mempersyaratkan setiap bangsa untuk mengerahkan pikiran dan seluruh potensi sumber daya yang dimilikinya untuk bisa survive dan bahkan exel dalam perebutan pemanfaatan kesempatan dalam berbagai sisi 
kehidupan. Ini berarti perlu adanya peningkatan sikap kompetitif secara sistematik dan berkelanjutan suber daya manusia melalui pendidikan dan pelatihan. Oleh karena itu, pendidikan dewasa ini harus diarahkan pada peningkatan daya saing bangsa agar mampu berkompetisi dalam persaingan global. Hal ini bisa tercapai jika pendidikan di sekolah diarahkan tidak semata-mata pada penguasaan dan pemahaman konsep-konsep ilmiah, tetapi juga pada peningkatan kemampuan dan keterampilan berpikir siswa, khususnya keterampilan berpikir tingkat tinggi yaitu keterampilan berpikir kritis (critical thinking skills). Artinya, guru perlu mengajarkan siswanya untuk belajar berpikir (teaching of thinking). Keterampilan berpikir kritis termasuk salah satu bagian dari keterampilan pembelajaran inovasi abad ke-21 yang memungkinkan siswa untuk menangani permasalahanpermasalahan di masa mendatang. Pentingnya berpikir kritis juga diungkapkan oleh Shakirova (2007) yaitu kemampuan berpikir kritis memungkinkan siswa secara efektif menangani masalah sosial, ilmiah, dan praktis. Sains atau Ilmu Pengetahuan Alam (IPA) merupakan salah satu persyaratan dalam penguasaan ilmu dan teknologi. Sains bukan hanya produk, namun juga proses. Sains berkembang melalui penelitian dan penyelidikan. Untuk dapat melakukan hal itu siswa perlu menguasai sejumlah keterampilan dasar sains yang disebut keterampilan proses sains.

$$
\text { Menurut Ango }
$$

keterampilan proses sains merupakan komponen penting dalam pelaksanaan proses belajar karena dapat mempengaruhi perkembangan pengetahuan siswa. Oleh karena itu, penilaian keterampilan proses sains merupakan komponen penting dalam pembelajaran kimia. Keterampilan proses adalah keseluruhan keterampilan ilmiah yang terarah digunakan untuk menemukan suatu konsep, prinsip, atau teori untuk mengembangkan konsep yang telah ada sebelumnya, ataupun untuk melakukan penyangkalan terhadap suatu penemuan. Kimia sebagai salah satu ilmu dasar dalam Ilmu Pengetahuan Alam mempunyai andil yang besar dalam kemajuan ilmu pengetahuan dan teknologi. Hal ini ditandai dengan berkembangnya teknologi di segala bidang yang menerapkan konsep-konsep kimia, sehingga selain keterampilan berpikir kritis, keterampilan proses sains merupakan faktor penting yang harus dimiliki siswa agar sukses di masa depan. Namun, pada kenyataannya keterampilan proses sains dan keterampilan berpikir kritis siswa secara nasional maupun internasional dinilai masih rendah dan kurang optimal. Menurut dokumen kurikulum 2013 yang dikeluarkan oleh Kementrian Pendidikan, hasil studi PISA (Program for International Student Assessment) menyebutkan bahwa negara Indonesia pada tahun 2012 menduduki peringkat 10 besar terbawah dari 65 negara dalam melek sains (Science literacy) (Erni, 2014). Hal ini menunjukkan bahwa kualitas pendidikan di Indonesia terutama keterampilan berpikir kritis dan keterampilan proses sains masih rendah. Rendahnya keterampilan berpikir kritis dan keterampilan proses sains siswa juga terjadi di beberapa SMA di Kabupaten Lampung Timur terutama pada mata pelajaran kimia.

Berdasarkan hasil angket analisis kebutuhan siswa dapat diketahui bahwa materi larutan penyangga merupakan salah satu materi yang sulit dipahami karena pada materi ini nilai UN siswa tahun 2013 , 2014 dan 2015 masih rendah. Upaya mengatasi kurang maksimalnya hasil belajar tersebut, perlu meningkatkan kualitas pembelajaran. Pembelajaran yang baik adalah pembelajaran yang tidak hanya 
melalui pemberian konsep saja, tetapi pembelajaran yang meningkatkan konsep yang dibangun oleh siswa sendiri. Oleh sebab itu guru harus menciptakan pembelajaran yang menuntut siwa untuk membangun konsep sendiri. Penggunaan metode pembelajaran inkuiri dalam pembelajaran adalah suatu alternatif yang dapat digunakan. Penelitian Abdi (2014) yang bertujuan untuk menyelidiki efek dari metode pembelajaran berbasis inkuiri pada prestasi akademik siswa dalam pembelajaran sains.

Hasil penelitian menunjukkan bahwa siswa yang diajarkan dengan pembelajaran berbasis inkuiri mencapai nilai yang lebih tinggi daripada yang diajarkan dengan metode tradisional. Karakteristik pembelajaran inkuiri terbimbing yang bersifat konstruktivis berpotensi untuk mengembangkan keterampilan proses sains dan kemampuan berpikir siswa, karena berbagai fenomena sekitar dapat diindera melalui panca indera. Pembelajaran konstruktivis mengembangkan kemampuan berpikir tingkat tinggi, berpikir kritis,berpikir analitis, aktivitas keterampilan proses sains yaitu meneliti dan berkomunikasi (Gazi, 2009). Keterampilan berpikir kritis dan proses sains dipengaruhi oleh kondisi lingkungan sekitar: kondisi laboratorium, perpustakaan, termasuk bahan ajar cetak sebagai sarana belajar siswa. Bahan ajar cetak merupakan salah satu sarana belajar yang berinteraksi secara langsung dengan siswa. Bahan ajar cetak yang digunakan di sekolah mempengaruhi keterampilan berpikir kritis dan proses sains siswa. Bahan ajar cetak mempengaruhi perkembangan kemampuan kognitif siswa dan kemampuan berpikir tinggi dalam mengklasifikasikan, membandingkan, membedakan, serta menganalisis (Oyola, 2013). Berdasarkan angket analisis pendahuluan menyebutkan bahwa 85,7 $\%$ guru di ketiga SMA tersebut jarang melakukan praktikum dengan alasan waktu yang terbatas dan tidak memiliki alat bahan yang lengkap. Sehingga sangat wajar jika siswa sangat awam dalam memakai alat-alat laboratorium. Selain kondisi laboratorium, berdasarkan wawancara dengan guru di tiga sekolah tersebut bahan ajar cetak yang digunakan belum separuhnya memberdayakan keterampilan berpikir kritis dan proses sains siswa. Hasil analisis bahan ajar pada SMA Kab. Lampung Timur pada satu kompetensi dasar larutan penyangga menunjukan bahwa isi buku hanya memuat keterampilan berpikir kritis yang berupa aspek interpretasi sebesar $50 \%$ dengan kriteria sedang, aspek analisis sebesar $33,3 \%$ dengan kriteria rendah, aspek penjelasan sebesar $0 \%$ dengan kriteria sangat rendah, aspek kesimpulan $41,65 \%$ dengan kriteria rendah, dan aspek evaluasi sebesar $8,35 \%$ dengan kriteria sangat rendah. Sedangkan keterampilan proses sains dinilai dari aspek mengamati $66,7 \%$ dengan kriteria tinggi, merumuskan hipotesis $0 \%$ dengan kriteria sangat rendah, merencanakan eksperimen, mengenda $8,35 \%$ dengan kriteria sangat rendah, mengendalikan variabel $0 \%$ dengan kriteria sangat rendah, menafsirkan data $83,3 \%$ dengan kriteria sangat tinggi, menyusun kesimpulan sementara $0 \%$ dengan kriteria sangat rendah, meramalkan $8,35 \%$ dengan kriteria sangat rendah, menerapkan konsep $83,3 \%$ dengan kriteria sangat tinggi, dan mengomunikasikan $58,3 \%$ dengan criteria tinggi. Berdasarkan hasil tersebut menunjukkan bahwa bahan ajar yang digunakan belum memberdayakan keterampilan berpikir kritis dan keterampilan proses sains dengan maksimal. Sehingga diperlukan pengembangan modul pada materi larutan penyangga.

Berdasarkan permasalahan yang 
telah dikemukakan maka diperlukan pengembangan bahan ajar untuk meningkatkan keterampilan berpikir kritis dan proses sains siswa yaitu,dengan melakukan pengembangan modul ajar di SMA Kabupaten Lampung Timur tersebut. Modul ajar yang menggunakan tahapan pembelajaran inkuiri terbimbing diharapkan meningkatkan keterampilan berpikir kritis dan proses sains, karena siswa dituntun untuk mengidentifikasi permasalahan dan hubungannya, mengajukan pertanyaan, membuat jawaban dari pertanyaan, membuat asumsi serta membuat kesimpulan yang logis (Hanson, 2006). Adapun tujuan dari penelitian ini adalah untuk : (1) mengembangkan modul kimia berbasis inkuiri terbimbing untuk meningkatkan keterampilan berpikir kritis dan keterampilan proses sains pada materi larutan penyangga (2) mengujii kelayakan modul kimia berbasis inkuiri terbimbing untuk meningkatkan keterampilan berpikir berpikir kritis dan keterampilan proses sains pada materi larutan penyangga (3) mengetahui efektivitas pembelajaran setelah menggunakan modul kimia berbasis inkuiri terbimbing pada materi larutan penyangga.

\section{Metode Penelitian}

Penelitian yang dilakukan merupakan penelitian pengembangan (research and development) yaitu pengembangan modul berbasis inkuiri terbimbing pada materi larutan penyangga untuk meningkatkan keterampilan berpikir kritis dan proses sains siswa. Pengembangan yang dilakukan menggunakan model prosedural dengan mengadaptasi model pengembangan Gorg dan Gall.

Langkah-langkah pengembangan menurut Borg dan Gall terdiri dari sepuluh tahapan yang harus dilakukan yaitu: 1) melakukan penelitian pendahuluan dan pengumpulan informasi (research and information collecting), 2) melakukan perencanaan (planning), 3) mengembangkan bentuk produk awal (develop preliminary form of product), 4) melakukan preliminary field testing, 5) melakukan revisi terhadap produk utama (main product revision), melakukan main field testing, yaitu memvalidasi produk pengembangan dalam skala lebih luas serta dibandingkan dengan produk kontrol apabila memungkinkan, 7) melakukan revisi terhadap produk operasional (operational product revision), 8) melakukan operational field testing yaitu melakukan uji validasi terhadap produk operasional yang dihasilkan, 9) melakukan revisi terhadap produk akhir (final product revision), 10) mendeseminasikan dan mengimplementasikan produk (dissemination and implementation). Pada penelitian ini hanya dilakukan dembilan tahapan dari sepuluh tahapan sebagai keterbatasan penelitian. Responden pada penelitian ini siswa kelas XI IPA pada tiga SMA di Kabupaten Lampung Timur yakni SMA Teladan Way Jepara, SMA Negeri 1 Labuhan Maringgai dan SMA Kosgoro Sribhawono serta guru Kimia kelas XI IPA. Pada uji coba skala terbatas, produk diuji cobakan pada 5 siswa dan 1 guru dari ketiga sekolah. Pada uji coba skala menengah produk diuji cobakan pada 4 guru dan 91 siswa kelas XI IPA dari ketiga sekolah. Pada uji coba skala luas produk diuji cobakan pada 2 kelas (kelas kontrol dan eksperimen) pada masing-masing sekolah. Instrumen yang digunakan dalam penelitian pengembangan ini yaitu angket, soal tes, lembar validasi, lembar penilaian antar peserta didik dan lembar observasi. Pengolahan data dalam penelitian ini dilakukan dengan menggunakan analisis deskriptif, meliputi analisis kelayakan dan analisis data hasil tes belajar. Metode 
pengumpulan data dalam penelitian ini adalah dengan teknik angket untuk mengetahui kelayakan modul dari ahli materi, ahli bahasa, ahli pembelajaran dan ahli media serta respon siswa dan guru, penilaian hasil belajar keterampilan dan sikap, teknik tes untuk penilaian hasil belajar pengetahuan, dan teknik penilaian antar peserta didik untuk keterampilan dan sikap. Pada tahap pengembangan draf I modul diperbaiki/direvisi berdasarkan saran/masukan dari para ahli. Sebelum diujicobakan modul yang dikembangkan divalidasi oleh 9 orang ahli dengan menggunakan formula Aiken. Kriteria yang digunakan adalah jika Indeks lebih besar atau sama dengan 0,74 maka tahapan pengembangan dapat dilanjutkan.

\section{Hasil Penelitian dan Pembahasan}

Data yang diperoleh dalam penelitian dan pengembangan antara lain data analisis kebutuhan, data validasi ahli dan praktisi, data hasil uji coba skala terbatas, skala menengah dan skala luas. Kegiatan yang dilakukan pada analisis kebutuhan yang berupa studi lapangan meliputi pemberian angket kepada siswa dan guru terhadap kebutuhan media pembelajaran, kondisi pembelajaran dikelas, ketersediaan bahan ajar, wawancara dengan siswa dan guru serta analisis hasil Ujian Nasional pada tiga tahun terakhir dan hasil Ulangan Harian mata pelajaran kimia tahun 2014/2015.

Secara garis besar jawaban dari hasil analisis kebutuhan dan wawancara terhadap 15 orang siswa adalah Sebanyak $53 \%$ siswa menyatakan bahwa mereka kesulitan mempelajari konsep kimia, baik dari buku ajar yang mereka pakai maupun dari penjelasan guru. Sebanyak 60\% siswa kurang antusias dalam dalam mengikuti pembelajaran kimia, dibuktikan juga dengan wawancara bahwa mereka cenderung cepat bosan jika guru menjelaskan karena terlalu rumit. Sebanyak $87 \%$ siswa menyatakan bahwa materi larutan penyangga sulit dipahami, mereka belum dapat membedakan sepenuhnya antara hidrolisis garam dan larutan penyangga. Selain itu, terlalu banyak rumus yang harus dihafalkan. Hal ini mengakibatkan hasil belajar siswa mengenai larutan penyangga masih tergolong rendah, hal ini dapat dilihat pada hasil ulangan harian tahun 2014/2015 yang masih banyak dibawah KKM. Untuk memahami konsep larutan penyangga, 80\% siswa setuju apabila dikembangkan bahan ajar seperti modul kimia berbasis inkuiri terbimbing. Selanjutnya adalah hasil analisis kebutuhan dan wawancara oleh guru tentang proses pembelajaran dapat disimpulkan sebagai berikut Hasil wawancara guru dan observasi kegiatan belajar mengajar dikelas terkait keterampilan berpikir kritis siswa dan proses sains kelas XI IPA menunjukkan bahwa kedua keterampilan tersebut masih belum maksimal. Berdasarkan analisis bahan ajar yang digunakan,dari kedua bahan ajar yang dianalisis belum menggunakan sintaks pembelajaran inkuiri terbimbing terutama dalam materi ajar larutan penyangga. Selain itu, bahan ajar yang digunakan banyak yang belum menggunakan indikator berpikir kritis dan indikator keterampilan proses sains. Analisis bahan ajar yang digunakan guru dilakukan untuk mengetahui presentase aspek keterampilam berpikir kritis dan keterampilan proses sains, dalam pembelajaran kimia seperti yang tercantum pada Tabel 1 dan 2. Berdasarkan hasil observasi dan wawancara dengan guru kimia di SMA Teladan Way Jepara, SMA Negeri 1 Labuhan Maringgai dan SMA Kosgoro Sribhawono diketahui bahwa metode 
pembelajaran yang digunakan oleh guru masih konvensional dan jarang sekali menggunakan model pembelajaran inkuiri, yang artinya siswa belum terbiasa melakukan pembelajaran menggunakan inkuiri, sehingga peneliti memutuskan untuk menggunakan model pembelajaran inkuiri terbimbing.

Peneliti berharap dengan pemilihan metode inkuiri terbimbing ini pembelajaran akan menjadi lebih efektif yang ditunjukkan dengan ketuntasan hasil belajar siswa secara individual dan klasikal. Penelitian dari Matthew dan Kenneth (2013) menunjukkan bahwa siswa yang diajarkan menggunakan metode pembelajaran inkuiri terbimbing memiliki nilai prestasi yang lebih baik daripada siswa yang belajar dengan menggunakan metode pembelajaran konvensional. Pada inkuiri terbimbing masalah dikemukakan oleh guru atau bersumber dari bahan ajar. Siswa bekerja untuk menemukan jawaban terhadap masalah tersebut di bawah bimbingan intensif guru (Amri, 2010).

Tabel 1 Analisis Bahan Ajar Kelas XI IPA Berdasarkan Aspek Keterampilan Berpikir Kritis Fascione (2015)

\begin{tabular}{|c|c|c|c|}
\hline No & $\begin{array}{l}\text { Aspek Keterampilan } \\
\text { Berpikir Kritis }\end{array}$ & $\begin{array}{l}\text { Skor } \\
(\%)\end{array}$ & Kriteria \\
\hline I. & Interpretasi & 50 & Sedang \\
\hline 2. & Analisis & 33,3 & Rendah \\
\hline 3. & Evaluasi & 41,65 & Sedang \\
\hline 4. & Kesimpulan & 8,35 & $\begin{array}{l}\text { Sangat } \\
\text { Rendah }\end{array}$ \\
\hline 5. & Penjelasan & 0 & $\begin{array}{l}\text { Sangat } \\
\text { Rendah }\end{array}$ \\
\hline
\end{tabular}

Tabel 2 Analisis Bahan Ajar Kelas XI IPA Berdasarkan Aspek Keterampilan Proses Sains Semiawan (1992)

\begin{tabular}{|c|c|c|c|}
\hline No & $\begin{array}{c}\text { Aspek } \\
\text { Keterampilam } \\
\text { Proses Sains } \\
\end{array}$ & $\begin{array}{l}\text { Skor } \\
(\%)\end{array}$ & Kriteria \\
\hline 1. & Mengamati & 66,7 & Tinggi \\
\hline 2. & Menafsirkan & 83,3 & $\begin{array}{l}\text { Sangat } \\
\text { Tinggi }\end{array}$ \\
\hline 3. & Meramalkan & 8,35 & $\begin{array}{l}\text { Sangat } \\
\text { Rendah }\end{array}$ \\
\hline 4. & $\begin{array}{l}\text { Merumuskan } \\
\text { hipotesis }\end{array}$ & 0 & $\begin{array}{l}\text { Sangat } \\
\text { Rendah }\end{array}$ \\
\hline 5. & $\begin{array}{l}\text { Menyusun } \\
\text { kesimpulan sementara }\end{array}$ & 0 & $\begin{array}{l}\text { Sangat } \\
\text { Rendah }\end{array}$ \\
\hline 6. & $\begin{array}{l}\text { Merencanakan } \\
\text { eksperimen }\end{array}$ & 8,35 & $\begin{array}{l}\text { Sangat } \\
\text { Rendah }\end{array}$ \\
\hline 7. & $\begin{array}{l}\text { Mengendalikan } \\
\text { variabel }\end{array}$ & 0 & $\begin{array}{l}\text { Sangat } \\
\text { Rendah }\end{array}$ \\
\hline 8. & Menerapkan konsep & 83,3 & $\begin{array}{l}\text { Sangat } \\
\text { Tinggi }\end{array}$ \\
\hline 9. & mengkomunikasikan & 58,3 & Tinggi \\
\hline
\end{tabular}

Preliminary Form of Product) yang dilakukan adalah membuat modul berbasis inkuiri terbimbing pada materi larutan peyangga . Pengembangan modul tahap awal dilakukan dengan berpedoman pada perencanaan tujuan, sub pokok bahasan, model pembelajaran inkuiri terbimbing, format dan visualisasi isi modul, format perangkat pembelajaran dan prosedur terkait pengembangan modul. Produk awal modul berbasis inkuiri terbimbing dikembangkan berdasarkan kisi-kisi indikator pada matriks yang telah sesuai dengan sintaks inkuiri terbimbing yang berisi aspek keterampilan berpikir kritis, dan keterampilan proses sains. tahap pengembangan draft produk awal, dilakukan penilaian dari beberapa ahli yang meliputi ahli materi, ahli media, ahli pembelajaran, ahli bahasa, dan praktisi pendidikan yaitu lima orang guru kimia. Tujuan dari penilaian ini untuk mengetahui kualitas kelayakan dari penilaian para ahli. Sebelum mendapatkan penilaian dari validator ahli (dosen) dan guru kimia, draft yang dikembangkan diberikan saran perbaikan sampai akhirnya diberikan penilaian. Validasi yang digunakan adalah validasi aiken dengan kriteria 
aiken sama dengan atau lebih dari 0.74 ( jika jumlah rater sebanya 9 orang) untuk tiap butir penilaiannya maka modul dikatakan valid dan dapat dilanjutan ketahap selanjutnya, indeks nilai 0,74 diperoleh dari banyaknya jumlah raters/validator yang memberikan penilaian terhadap instrumen. Data validasi ahli dan guru dianalisis, jika hasil validasi ahli dan guru belum layak maka dilakukan revisi terhadap produk sesuai saran ahli dan guru. Setelah validasi dilakukan, draf produkkemudian direvisi berdasarkan saran dan masukan dari para validator. Setelah itu dilakukan perhitungan hasil penilaian para validator terhadap modul berbasis inkuiri terbimbing, diperoleh hasil bahwa modul yang dikembangkan valid dengan perolehan nilai

Tahapan selanjutnya adalah tahap pengembangan bentuk awal produk (Develop perangkat pembelajaran diperoleh indeks validasi $(\mathrm{V})>0.74$ sehingga analisis dapat validasi Aiken 0,954 . Selain validasi draf produk yang berupa modul, dilakukan juga validasi perangkat pembelajaran lainnya seperti silabus, RPP, penilaian kognitif,afektif dan psikomotor sebagai pelengkap penelitian. Berdasarkan hasil perhitungan uji validasi Aiken pada instrumen dilanjutkan dan instrumen perangkat pembelajaran layak digunakan.

Setelah melalui tahapan validasi dan dilakukan revisi pada draf I maka didapatkan modul draf II, langkah selanjutnya adalah melakukan uji coba terbatas. Tujuan dari uji coba skala terbatas adalah untuk mengetahui keterbacaan dari modul yang dikembangkan. Uji coba skala terbatas dilakukan dengan cara memberikan angket penilaian kepada siswa dan guru. Uji coba terbatas dilakukan di SMA Teladan Way Jepara, SMA Negeri 1 Labuhan Maringgai dan SMA Kosgoro dengan 1 guru dan 5 siswa di masingmasing sekolah yang digunakan dalam penelitian. Hasil uji coba skala terbatas yang dilakukan pada ke tiga sekolah tersebut dapat disimpulkan jika dilihat dari aspek isi berdasarkan angket siswa menunjukkan bahwa sebagian siswa terutama sekolah dengan kategori sedang dan rendah, sedikit kesulitan dalam memahami materi yang terdapat dalam modul. Hal ini dikarenakan siswa terbiasa menerima konsep terlebih dahulu dari guru sehingga mereka membutuhkan adaptasi dalam mempelajari modul yang terdapat sintaks inkuiri terbimbing. Namun, berbeda dengan hasil angket guru. Mereka berpendapat bahwa materi yang terdapat dalam modul sangat menarik untuk dipelajari karena dapat menambah pengetahuan siswa. Dilihat dari aspek bahasa, baik angket siswa maupun guru sebagian besar menunjukkan bahwa penggunaan tulisan dan bahasa dalam menjabarkan materi modul sudah cukup baik. Namun, ada beberapa tanda hubung dan tanda spasi yang masih terdapat kesalahan dan ada sebagaian bahasa soal yang terlalu tinggi yang membuat siswa bingung untuk memahami. Dilihat dari aspek penyajian, sebagian besar siswa dan guru menyatakan bahwa modul dapat digunakan sebagai media pembelajaran. Modul sangat mampu menumbuhkan keterampilan berpikir kritis dan menyajikan akrivitas keterampilan proses sains siswa. Dilihat dari aspek isi berdasarkan angket siswa dan guru menunjukkan bahwa desain modul, kombinasi warna yang disajikan sudah cukup menarik. Namun ada beberapa kombinasi warna yang terlalu ramai yang sebaiknya dikurangi. Setelah dilakukan uji skala terbatas dan melakukan revisi. Tahap selanjutnya adalah melakukan uji coba skala menengah. Data hasil uji keterbacaan modul pada tahap uji coba skala menengah dilakukan oleh 4 guru dan 91 siswa dari SMA Teladan Way Jepara, SMA Negeri 1 Labuhan Maringgai dan SMA Kosgoro. Masing-masing siswa diberi angket untuk memberi nilai dan saran pada modul. Hasil penilaian pada 
uji skala menengah dapat dilihat pada tabel 4.3. Data hasil penilaian siswa terhadap kualitas modul yang dikembangkan, diperoleh nilai rata-rata persentase sebesar 85,55 yang menunjukkan bahwa modul yang dihasilkan memiliki kategori baik.

Tabel 3 Hasil penilaian siswa dan guru pada uji coba skala menengah terhadap modul yang dikembangkan

\begin{tabular}{|c|c|c|c|c|c|}
\hline \multirow[t]{2}{*}{ No } & \multirow{2}{*}{$\begin{array}{c}\text { Aspek } \\
\text { Penilaian } \\
\text { Kualitas }\end{array}$} & \multicolumn{2}{|c|}{ Siswa } & \multicolumn{2}{|c|}{$\overline{\text { Guru }}$} \\
\hline & & $\begin{array}{c}\text { Persentase } \\
(\%)\end{array}$ & Kategori & $\begin{array}{c}\text { Persentase } \\
(\%)\end{array}$ & Kategori \\
\hline 1. & Isi Materi & 85,16 & Baik & 87,5 & Baik \\
\hline 2. & Bahasa & 86,45 & Baik & 89.58 & Baik \\
\hline 3. & Penyajian & 85,26 & Baik & 91,67 & Baik \\
\hline \multirow[t]{2}{*}{4.} & Kegrafikan & 85,35 & Baik & 89,58 & Baik \\
\hline & Rata-Rata & 85,55 & Baik & 89,58 & Baik \\
\hline
\end{tabular}

Hasil penilaian guru diperoleh nilai rata- rata persentase sebesar 89,58 yang menunjukkan bahwa modul yang dikembangkan memiliki kategori baik. Sehingga dapat dilanjutkan ke tahap selanjutnya dengan sedikit revisi dan masukan dari para responden. Kesimpulannya adalah modul inkuiri terbimbing layak digunakan dalam proses pembelajaran. Berdasarkan uji coba skala menengah yang dilakukan, didapatkan saran dan masukan dari siswa dan guru. Selanjutnya hasil revisi modul digunakan pada uji skala luas.

Setelah dilakukan uji coba skala terbatas dan uji coba skala menengah, selanjutnya dilakukan uji coba skala luas. Uji coba skala luas dilakukan dengan mengujicobakan modul berbasis inkuiri terbimbing di tiga kelas sebagai kelas dengan perlakuan dan tiga kelas sebagai pembanding dan tanpa perlakuan dengan masingmasing 1 kelas pada setiap sekolah dengan kategori tinggi, sedang, dan rendah yang digunakan dalam penelitian. pada kelas kontrol kegiatan pembelajaran tidak menggunakan modul berbasis inkuiri terbimbing. Guru menjelaskan kepada siswa dengan metode dan model yang biasa digunakan. Pembelajaran dilaksanakan pada 4 kali pertemuan. Uji coba skala luas bertujuan untuk memperoleh nilai keefektifan modul berbasis inkuiri terbimbing yang dikembangkan dan ketercapaian keterampilan berpikir kritis dan proses sains siswa. Uji coba skala luas ini siswa dan guru juga memberikan penilaian, saran dan masukan pada modul berbasis inkuiri terbimbing.

Pada uji coba skala luas, dilakukan pretest dan postest dengan soal pilihan ganda yang terdapat indikator keterampilan berpikir kritis dan proses sains, penilaian dengan angket afektif dan penilaian psikomotorik siswa terhadap praktikum yang telah dilakukan. Kelas dengan perlakuan yaitu diberikan modul dan melakukan praktikum dilakukan penilaian psikomotor. Untuk mengetahui efektivitas modul berbasis inkuiri terbimbing melalui analisis prestasi belajar, peneliti menggunakan gain yang ternormalisasi $(N$-gain $) \quad$ untuk mengetahui peningkatan hasil pretest dan post test terhadap dua kelompok, yaitu kelompok kelas kontrol dan eksperimen. Pada uji coba skala luas, hasil $N$ - Gain antara kelas kontrol dan kelas eksperimen pada masing-masing sekolah digunakan untuk mencari normalitas, homogenitas, serta uji t. Berdasarkan hasil uji normalitas di ketiga sekolah didapatkan bahwa nilai signifikansi >0,05, dengan demikian sampel di ketiga sekolah berdistribusi normal. Berdasarkan hasil uji homogenitas di ketiga sekolah didapatkan bahwa nilai signifikansi $>0,05$, dengan demikian sampel di ketiga sekolah memiliki varians antar kelompok yang sama. Setelah melakukan uji normalitas dan homogenitas dilakukan uji lanjut berupa uji $\mathrm{t}$ pihak kanan Berdasarkan perhitungan didapatkan uji $t_{\text {hitung }}$ pada SMA Teladan Way jepara dengan taraf signifikansi 0,05 didapatkan nilai $t_{\text {hitung }}$ $(3,88)>t_{\text {tabel }}(1,64)$, menunjukkan bahwa 
$\mathrm{H}_{\mathrm{o}}$ ditolak atau $\mathrm{H}_{1}$ diterima. Ini berarti bahwa modul kimia berbasis inkuiri terbimbing pada materi larutan penyangga yang diterapkan di SMA Teladan Way Jepara efektif dan lebih baik jika dibandingkan pada kelas kontrol yang tidak menggunakan modul kimia berbasis inkuiri terbimbing. Dengan demikian modul kimia berbasis inkuiri terbimbing efektif digunakan untuk sekolah dengan kategori tinggi. Uji $t_{\text {hitung }}$ pada SMA Negeri 1 Labuhan Maringgai dengan taraf signifikansi 0,05 didapatkan nilai $t_{\text {hitung }}(3,098)>t_{\text {tabel }}$ $(1,64)$, menunjukkan bahwa $\mathrm{H}_{\mathrm{o}}$ ditolak atau $\mathrm{H}_{1}$ diterima. Ini berarti bahwa modul kimia berbasis inkuiri terbimbing pada materi larutan penyangga yang diterapkan di SMA Negeri 1 Labuhan Maringgai efektif dan lebih baik jika dibandingkan pada kelas kontrol yang tidak menggunakan modul kimia berbasis inkuiri terbimbing. Dengan demikian modul kimia berbasis inkuiri terbimbing efektif digunakan untuk sekolah dengan kategori sedang. Uji $\mathrm{t}_{\text {hitung }}$ pada SMA Kosgoro dengan taraf signifikansi 0,05 didapatkan nilai $t_{\text {hitung }}$ $(5,11)>t_{\text {tabel }}(1,64)$, menunjukkan bahwa $\mathrm{H}_{\mathrm{o}}$ ditolak atau $\mathrm{H}_{1}$ diterima. Ini berarti bahwa modul kimia berbasis inkuiri terbimbing pada materi larutan penyangga yang diterapkan di SMA Negeri 1 Labuhan Maringgai efektif dan lebih baik jika dibandingkan pada kelas kontrol yang tidak menggunakan modul kimia berbasis inkuiri terbimbing. Dengan demikian modul kimia berbasis inkuiri terbimbing efektif digunakan untuk sekolah dengan kategori rendah. Hasil penilaian pada uji coba skala luas terhadap modul yang dikembangkan oleh siswa dan guru dapat dilihat pada Tabel 4.4.
Tabel 4 Hasil penilaian siswa dan guru padauji coba skala terbatas terhadap modul yang dikembangkan

\begin{tabular}{llllll}
\hline No & $\begin{array}{c}\text { Aspek } \\
\text { Penilaian } \\
\end{array}$ & Kualitas & \multicolumn{2}{c}{ Siswa } & \multicolumn{2}{c}{ Guru } \\
\cline { 3 - 6 } & & $\begin{array}{c}\text { Persentase } \\
(\%)\end{array}$ & Kategori & $\begin{array}{c}\text { Persentase } \\
(\%)\end{array}$ & Kategori \\
\hline 1. & Isi Materi & 85,28 & Baik & 91,67 & Baik \\
2. & Bahasa & 86,67 & Baik & 90,28 & Baik \\
3. & Penyajian & 86,57 & Baik & 94,4 & Baik \\
4. & Kegrafikan & 87,13 & Baik & 93,06 & Baik \\
& Rata-Rata & 86,41 & Baik & 92,36 & Baik \\
\hline
\end{tabular}

Selanjutnya dilalukan analisis terhadap indikator keterampilan berpikir kritis dan keterampilan proses sains. Soal pretes dan postest yang digunakan selain berfungsi sebagai alat evaluasi juga berfungsi sebagai alat penilaian untuk mengukur keterampilan berpikir kritis. Hasil ketercapaian indikator keterampilan berpikir kritis yang diperoleh dari perhitungan pada ketiga SMA dapat dilihat pada Gambar 4.1, 4.2 dan 4.3 Pada Gambar 4.1 dapat dilihat bahwa SMA dengan kategori tinggi terjadi peningkatan disetiap indikator keterampilan berpikir kritis setelah menggunakan modul berbasis inkuiri terbimbing. Peningkatan signifikan terdapat pada semua indikator.

Gambar 4.2 menunjukkan bahwa SMA dengan kategori sedang, terjadi peningkatan disetiap indikator keterampilan berpikir kritis setelah menggunakan modul berbasis inkuiri terbimbing. Peningkatan signifikan terdapat pada indikator kesimpulan, analisis dan evaluasi. Gambar 4.3 menunjukkan bahwa SMA dengan kategori rendah terjadi peningkatan disetiap indikator keterampilan berpikir kritis setelah menggunakan modul berbasis inkuiri terbimbing. Peningkatan signifikan terdapat pada indikator kesimpulan. 


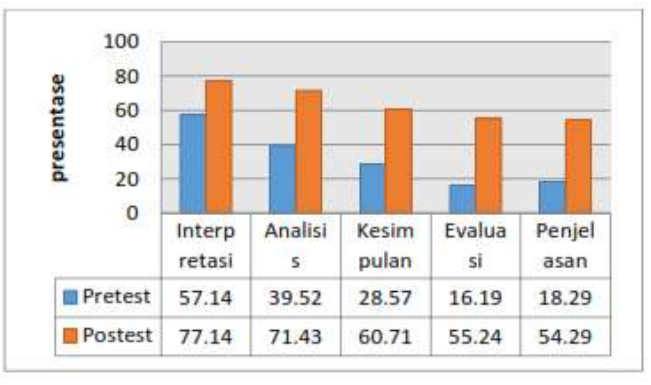

Gambar 1. Diagram Hasil Ketercapaian Keterampilan Berpikir Kritis SMA Kategori Tinggi

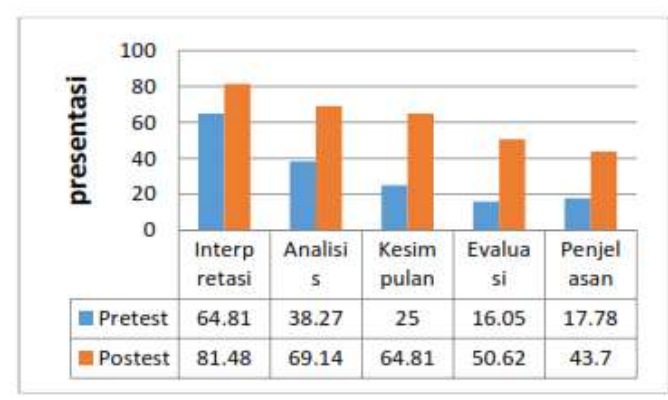

Gambar 2 Diagram Hasil Ketercapaian Keterampilan Berpikir Kritis SMA Kategori Sedang

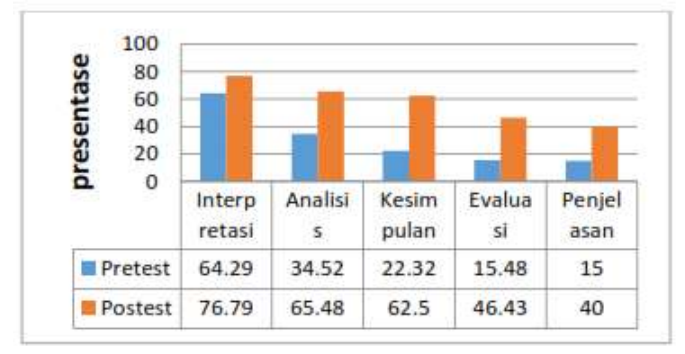

Gambar 3 Diagram Hasil Ketercapaian Indikator Keterampilan Berpikir Kritis SMA Kategori rendah

Berdasarkan Gambar 1, 2 dan 3, serta rata-rata hasil ketercapaian seluruh indicator keterampilan berpikir kritis setelah diberi modul siswa SMA Teladan Way Jepara memiliki keterampilan berpikir kritis lebih tinggi dibandingkan dengan SMA Negeri 1 Labuhan Maringgai dan SMA Kosgoro. SMA Kosgoro memiliki keterampilan berpikir kritis terendah. Selain berdasarkan hasil penilaian, dapat dilihat melalui kegiatan pembelajaran di kelas. Siswa- siswa yang berada disekolah dengan kategori tinggi yaitu SMA Teladan Way Jepara jauh lebih banyak yang aktif dalam bertanya apabila ada kesulitan, banyak yang berhasil menjawab uji kompetensi 1 dan 2 dalam modul dan diskusi kelompok sangat berjalan lancar dibandingkan siswa di sekolah sedang dan rendah. Pada kegiatan pembelajaran siswa disekolah rendah yaitu SMA Kosgoro masih banyak siswa yang bingung dalam mengerjakan uji kepahaman dalam modul dan harus dipancing terlebih dahulu untuk mengingat materi yang sebelumnya sudah diberikan oleh guru, sehingga peranan guru dalam membimbing sangat dibutuhkan. Meskipun demikian, indikator berpikir kritis di semua sekolah mengalami peningkatan. Dengan demikian, modul inkuiri terbimbing dapat meningkatkan keterampilan berpikir kritis siswa.

Modul berbasis inkuiri terbimbing efektif untuk meningkatkan keterampilan berpikir kritis, hasil yang didapat sesuai dengan teori yang menyebutkan bahwa keterampilan bepikir kritis yang terintregasi dalam pembelajaran termasuk dalam modul, memungkinkan siswa untuk mencapai nilai yang lebih baik (Savich, 2009). Pelatihan- pelatihan keterampilan berpikir kritis yang terangkum dalam literatur baik modul maupun buku berpotensi untuk melatihkan keterampilan berpikir kritis siswa sehingga tidak hanya mendorong siswa untuk mendapatkan fakta dan pengetahuan dari teks saja tetapi juga mendukung siswa untuk mendapatkan gagasan, pemahaman dan sudut pandang yang baru sehingga mempu meningkatkan hasil belajar siswa (Hazeli dan Rezali, 2013; Khatib dan Alizadeh, 2012; Lunenburg, 2012). Selanjutnya adalah analisis keterampilan proses sains siswa. ratarata hasil ketercapaian seluruh indikator keterampilan proses sains sebelum diberi modul dan setelah diberi modul yang ditunjukkan pada Gambar 4, siswa di SMA Teladan Way Jepara memiliki keterampilan proses sains yang lebih tinggi dibandingkan dengan SMA Negeri 1 Labuhan Maringgai dan SMA 
Kosgoro.

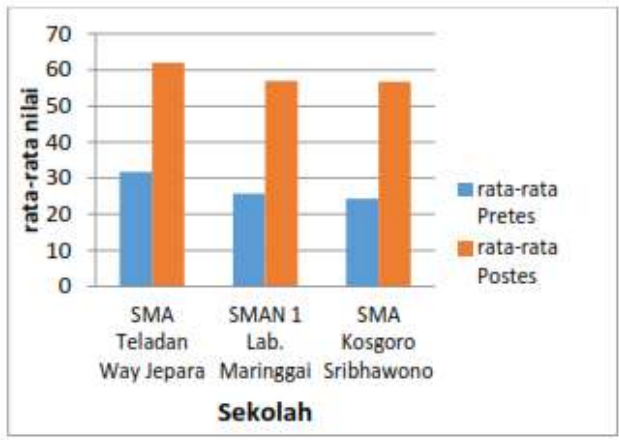

Gambar 4. Rata-rata Hasil Ketercapaian Seluruh Indikator Keterampilan Proses Sains

Selain berdasarkan hasil penilaian, dapat dilihat melalui kegiatan pembelajaran dikelas. Siswa-siswa yang berada disekolah dengan kategori tinggi yaitu SMA Teladan Way Jepara jauh lebih terampil dalam menggunakan alatalat praktikum, banyak yang aktif dalam bertanya apabila ada kesulitan, keterampilan mengkomunikasikan juga sangat baik, hal ini terlihat ketika siswa diminta untuk presentasi hasil disukusi kelompoknya. Pada kegiatan pembelajaran siswa disekolah rendah yaitu SMA Kosgoro masih banyak diperlukan bimbingan guru dalam menggunakan alat-alat praktikum, dikarenakan siswa hampir tidak pernah diajak untuk melakukan praktikum. Bahkan banyak siswa yang belum tahu bentuk dari indikator universal, sehingga peranan guru dalam membimbing sangat dibutuhkan. Meskipun demikan, indikator proses sains di semua sekolah mengalami peningkatan baik di sekolah tinggi, sedang maupun rendah. Dari ketiga sekolah indikator keterampilan proses sains yang paling meningkat adalah indikator mengamati. Hasil analisis tersebut sepadan dengan penelitian Ongowo (2013) yang hasilnya selama kurun waktu sepuluh tahun, keterampilan proses sains siswa yang pencapaiannya paling tinggi yaitu keterampilan mengobservasi atau mengamati. Hasil ini juga sepadan dengan penelitian Afolabi dan Akinbobola (2010) yang menyatakan bahwa keterampilan proses sains dasar lebih tinggi pencapaiannya daripada keterampilan proses sains terpadu. Dengan meningkatnya keterampilan proses sains disemua indikator, baik disekolah dengan kategori tinggi, sedang dan rendah menunjukkan bahwa modul inkuiri terbimbing dapat meningkatkan keterampilan proses sains siswa. Hal ini juga sesuai dengan penelitian yang dilakukan oleh Lati, W., Supasorn, S., and Promarak, V. (2012), pendekatan inkuiri telah teruji sebagai pendekatan pembelajaran yang efektif untuk meningkatkan pemahaman konsep, keterampilan berpikir kritis dan keterampilan proses sains di Thailand.

\section{Kesimpulan dan Rekomendasi}

Berdasarkan hasil analisis data dan pembahasan yang telah dilakukan dapat disimpulkan:

1. Telah dikembangkan modul kimia berbasis inkuiri terbimbing pada materi larutan penyangga dengan menggunakan 9 tahapan prosedur Borg and Gall. Modul tersebut dapat meningkatkan keterampilan berpikir kritis dan keterampilan proses sains.

2. Modul kimia berbasis inkuiri terbimbing pada materi larutan penyangga telah diuji kelayakannya, baik dari aspek isi materi, bahasa, penyajian dan kegrafikan. Didapatkan presentase uji kelayakan $>85,1 \%$ dengan kategori baik. Modul yang telah diuji kelayakannya dapat meningkatkan keterampilan berpikir kritis dan keterampilan proses sains.

3. Produk modul kimia berbasis inkuiri terbimbing pada materi larutan penyangga efektif digunakan di SMA Teladan Way Jepara, SMA Negeri 1 Labuhan Maringgai dan SMA Kosgoro Sribhawono Kabupaten Lampung Timur. Keefektifan ditunjukkan dengan rata-rata prestasi 
belajar kelas eksperimen lebih tinggi dibandingkan kelas kontrol. Sehingga dapat disimpulkan bahwa kelas yang menggunakan modul kimia berbasis inkuiri terbimbing memiliki prestasi belajar lebih baik dibandingkan dengan kelas yang tidak menggunakan modul. Keterampilan berpikir kritis dan proses sains siswa meningkat pada setiap sekolah dengan kategori tinggi, sedang dan rendah

Rekomendasi sebelum menggunakan modul hasil pengembangan ini adalah :

1. Modul berbasis Inkuiri Terbimbing pada materi larutan penyangga disarankan digunakan oleh guru dan siswa sebagai alternatif bahan ajar yang mampu meningkatkan keterampilan berpikir kritis dan proses sains siswa.

2. Modul berbasis Inkuiri Terbimbing perlu diimplementasikan dalam pembelajaran materi lain yang memiliki karakteristik yang sama dengan materi larutan penyangga

3. Sebelum menerapkan Modul kimia berbasis inkuiri terbimbing pada materi pokok hidrolisis garam hasil pengembangan, sebaiknya memahami cara penerapan metode pembelajaran inkuiri

\section{Daftar Pustaka}

Abdi, A. (2014). The Effect of Inquiry-based Learning Method on Students' Academic Achievement in Science Course. Universal Journal of Educational Research. 2(1): 37-41.

Amri, S dan Ahmadi, K. I. (2010). Proses Pembelajaran Kreatif dan novatif dalam Kelas. Jakarta. Prestasi Pustaka Raya.

Ango, M.L. (2002). Mastery of Science Process Skills and Their Effective Use in the Teaching of Science: An Educology of Science Education in the Nigerian Context. International
Journal of Educology 1 (16).

Akinbobola, A.O., and Afolabi, F. (2010). Analysis of science process skills inWest African senior secondary school certificate physics practical examinations in Nigeria. AmericanEurasian Journal of ScientificResearch, 5 ( 4), pp 234240

Erni, Hestia. (2014). Profil Keterampilan Proses Sains Mahasiswa Program Pendidikan Jarak Jauh SI PGSD Universitas Sriwijaya. Seminar Proseeding of The International Seminar of Science Education, 27 Oktober 2007. Bandung

Fascione, P.A. (2015). Critical Thinking, What It Is and Why I Counts. California: California Academic Press.

Gazi, Z. A.(2009). Implementing Constructivist Approach Into Online Course Designs in Distance Education Institute at Eastern Mediterranean University. The Turkish Online Journal of EducationalTechnology: Eastern Mediterranean University.

Hanson, D. M. (2006). Instructor's Guide to Process-Oriented Guided-Inquiry Learning.Stony Brook University:Pacific Crest.

Hazeli, Z. dan rezali, F. (2013). The Effect of Teaching Critical Thinking on Educational Achievment and Test Anxiety Among Junior High School Student in Savech. European Online Journal of Natural and Social Sciences. 2(2): 168-175

Khatib, M. san Alizadeh, I. (2012). Critical Thinking Skill trough Lyteracy and Non- Literary Text in English Classes. International Journal of Linguistic. 4(4): 563-580.

Lati, W., Supasorn, S., and Promarak, V. (2012). Enhancement of learning achievement and integrated science process skills using science inquiry learning act ivities of chemicalreaction rates. Elsavier 
Procedia Sosial and Behavioral Sciences, 46, 4471-4475

Lunenburg, F.C. (2011). Critical Thinking and Constructivism Techniques for Improving Student Achievment. National Forum Teacher Education Journal. 21(3) 1-9

Matthew, B. M. and Kenneth, I.O. 2013. A Study on The Effects of Guided Inquiry Teaching Method on Students Achievement in Logic. International Research. 2(1): 134140

Oyola, J. E. (2013). Instructional Materials: A Platform to Enhance Cognitive Skills and Writing Development. ColombApplLinguistik Journal. 12: 0123- 4641. Bogota: Universidad EAN.

Savich., C. 2009. Improving Critical Thinking Skill in History. An Online Journal for Teacher Researcher. 11(2): 1-12

Semiawan, C., 1992, Pendekatan Keterampilan Proses, Jakarta: PT. Gramedia

Shakirova DM (2007). Technology for the shaping of college students' and upper- grade students' critical thinking. Russ. Educ. Soc., 49(9): 42-52. 